\title{
THE IMPORTANCE OF HELPERS TO THE IMPRISONED PAUL IN THE BOOK OF ACTS
}

\author{
Brian M. Rapske \\ 1. Introduction
}

From Acts 21 to the end and encompassing a period well in excess of four years the apostle Paul was imprisoned. The peristasis catalogues of 2 Corinthians mention many other imprisonments $(6: 5 ; 11: 23)$ in the period before Acts $20: 2 a .^{1}$ Of these, Luke records only Paul's Philippian imprisonment (16:16-40; cf. 1 Thes. 2:2), passing over others in silence. Clearly Paul was frequently in confinement and for long periods of time. How did he cope?

It is unfortunate that this question, which presses for a practical answer, often draws a largely theological response, succumbs to triumphalist assertions concerning Paul's indomitable spirit, or simply dies in the asking. Asked again, how practically speaking, did he cope? The answer is that Paul received help.

Admittedly, Luke does not dwell upon the helpers of the prisoner Paul or their helping activities to any great extent. But neither does he ignore them. It is the purpose of this paper to examine a few helpers and the help they render Paul in the book of Acts. When analyzed against the much fuller background of prison helpers and helping behaviours in the Greco-Roman world, these Lucan snippets yield some surprising and helpful insights.

\section{Kinds of Helpers}

1. Friends, Disciples and Slaves: The virtue of helping a prisoner because of true friendship is mooted in a letter of Seneca, dated c. 63-5 AD. He argues there that friendships should not be made simply to mitigate or escape disasters such as imprisonment. 'He who regards himself only, and enters

${ }^{1}$ Cf. V.P. Furnish, II Corinthians (AB 32A, Garden City, Doubleday 1984) 354 on the possible interpretations of the plural 'imprisonments'. 
upon friendships for this reason, reckons wrongly', ${ }^{2}$ writes Seneca. Rather, the true friend seeks out one 'by whose sick-bed he himself may sit, someone a prisoner in hostile hands whom he himself may set free' ${ }^{3}$

Some friends may be motivated to help the prisoner by what we might call affection. The emotionally depressed prisoner Publius Vitellius (31AD), ${ }^{4}$ the Jewish prince Agrippa (37 AD), ${ }^{5}$ and Antiphilus and Deinias in Lucian's Toxaris (c. 163 AD), ${ }^{6}$ are attended by friends who show such self-disregarding affection.

The solidarity of friends with the prisoner sometimes has a political or moral aspect to it. The 'many good men' who accompany the condemned Phocion and his compatriots to the prison in Athens (318 BC), Cleomenes and his friends (220 BC) who are all under house arrest for trying to topple the Egyptian monarchy, ${ }^{7}$ and the body of Roman senators who accompany the younger Cato $(59 \mathrm{BC})$ when he is taken to prison at Caesar's command, ${ }^{8}$ demonstrate the interweave of friendship and political or moral solidarity.

Other helpers may be specified by reference to their philosophical or religious solidarity with the prisoner. The Life of Apollonius of Tyana, a substantial proportion of which comes by way of his companion Damis, ${ }^{9}$ gives some insight into

\footnotetext{
${ }^{2}$ Seneca, Ep. ad Lucilium 9.8. [Unless otherwise indicated, references to extrabiblical Greek and Latin texts are cited from the Loeb Classical Library].

${ }^{3}$ Ibid.

4Suetonius, Vit. 7.2.3.

5Josephus, Ant.18.204 [18.6.71]. Other friends are also permitted to visit and attend to Agrippa from what is said by Josephus (Ibid. 18.203 [18.6.7]). In addition to affection, there might stand political opportunism. When he returned to Jerusalem as king, Agrippa gave to Silas the command of his army in consideration of the hardships he was willing to share with Agrippa (Ibid.19.299 [19.6.3]).

'Lucian, Tox . 27, and 17. A.M. Harmon, states that the stories, declared on oath in the text to be authentic and recent happenings, 'are the thing, and the dialogue is just a framing-tale in which to display them'. (Lucian, Tox. [LCL] p. 101).

${ }^{7}$ Polybius 5.39.1-5.

${ }^{8}$ Plutarch, Cat.Mi. 31.1f.; ibid. Caes. 14.7. Plutarch calls the senators 'influential men' in the latter passage. The significance of the action is expressed in the words of Marcus Petreius. According to Dio Cassius 38.3.2. Petreius is said to have told Caesar as he turned to go, 'I prefer to be with Cato in prison rather than here with you'.

${ }^{9} \mathrm{Cf}$. G. Anderson Philostratus: Biography and Belles Lettres in the Third
} 
the friends and disciples of the philosophers. Despite the danger of prison and death, Damis willingly goes with his teacher to Rome; in Apollonius' words, 'accompanying me in all I do' ${ }^{10}$ The philosopher Musonius, a contemporary of Apollonius, has in his Roman imprisonment under Nero, a counterpart to Damis in the person of Menippus. ${ }^{11}$ Apollonius demonstrates fraternity with a fellow philosopher when he writes to Musonius that he is prepared to share in the latter's imprisonment and to assist him in securing his release. ${ }^{12}$ In Judaism there are examples in the disciples who attend to John the Baptist. ${ }^{13}$ A fraternal relationship exists between Rabbi Joshua the gritsmaker and the imprisoned Rabbi Akiba for whom he cares. ${ }^{14}$ Christian examples would include the disciples of the Christian martyr Montanus (259 AD) ${ }^{15}$ and the newly converted 'adjutant who was head of the gaol'16 and who assisted Perpetua and Felicitas (203 AD). The Apocryphal Acts also describe the visits and ministrations of convert or disciple helpers in prisons. ${ }^{17}$

Finally, the helper might be owned by the prisoner or otherwise beholden to him. The slaves of Cleomenes (220 BC), ${ }^{18}$ the slaves of the consular Paetus (42 AD), ${ }^{19}$ and the freedmen Marsyas and Stoecheus who attend the Jewish prince Agrippa (37 AD) ${ }^{20}$ are examples.

2. The Jailer, 'We' and Aristarchus: Looking to Acts, we find explicit reference to several individual helpers: the

Century BC (London, Croom Helm 1986) 163, on its historical reliability.

${ }^{10}$ Philostratus, VA 7.15.

${ }^{11}$ Ibid. 4.46.

${ }^{12}$ Ibid.

${ }^{13}$ Mt., 11:2; 14:12. Cf. Mk., 6:29; Lk., 3:20; 7:18-24.

14. Epstein, (ed.) The Babylonian Talmud (London, Soncino 1938) [hereafter Talm.] Mo'ed III: Erub. $21 b$.

${ }^{15} \mathrm{H}$. Musurillo, (ed. and tr.) The Acts of the Christian Martyrs (Oxford, Clarendon 1972) [hereafter Mart.] Mart. Mont. \& Luc. 19.2.

${ }_{16}$ Mart. Perp. \& Felic. 16.4.

${ }^{17}$ E. Hennecke, et al., New Testament Apocrypha: Vol. Two (Philadelphia, Westminster 1965) [hereafter Apoc.] Apoc. Acts of Thomas 10.119; 13.150-1 (first half 3rd cent. AD) Apoc. Acts of Paul 3.17-20 (c. 185-95 AD); Apoc. Acts of Andrew B.5 (c.190 AD).

${ }^{18}$ Polybius 5.39. 1-5.

${ }^{19}$ Pliny, Ep. 3.16.

${ }^{20}$ Josephus, Ant. 18.204 [18.6.7]. Josephus recounts the kindness done to Agrippa by a slave of Gaius who gave him a drink of cold water. (Ibid. 18.193 [18.6.6]). 
Philippian jailer (16:27-36) the writer of the 'we' source whom many identify as Luke (27:lff.) ${ }^{21}$ and Aristarchus (27:2). In the case of the Philippian jailer, we clearly have a newly-minted convert or disciple. Unusual is the fact that he helps from within the prison system. The capacity in which Luke and Aristarchus attend Paul at (27:1ff.,) however, is variously assessed. They have been identified as Paul's friends or associates, $^{22}$ slave attendants ${ }^{23}$ and, in the case of Aristarchus, a fellow-prisoner. ${ }^{24}$

Aristarchus, appearing in Acts previously in connection with the riot at Ephesus (19:29) and the Jerusalem collection (20:4), is probably the same person mentioned at Colossians 4:10 and Philemon 24. Because Paul designates him 'my fellow prisoner' at Colossians 4:10 it is assumed by some that he accompanies Paul as a fellow prisoner at Acts 27:2. This, for several reasons, is unlikely. First, we should expect in two epistles, where many of the same individuals are mentioned, that there would be some consistency in assigning epithets such as

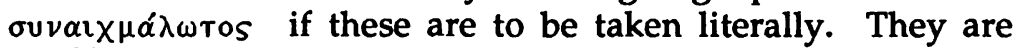
not. ${ }^{25}$ Second, there is lack of close physical proximity in the text between Aristarchus and those designated prisoners. Only after the companion(s) of the 'we' source are mentioned and dis-

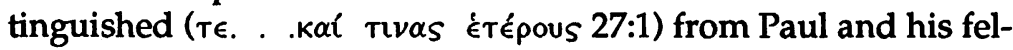
low prisoners who are placed in the charge of the centurion, and after the travel arrangements are indicated, is Aristarchus

${ }^{21}$ J.V. Bartlett, The Acts (CBNT 5, Edinburgh, T.C. and E.C. Clark 1901) 368: suggests that the 'we' may include others beyond Luke and Paul.

${ }^{22}$ So e.g., F.F. Bruce, The Book of Acts (NICNT; 1954, rev. ed. Grand Rapids, Eerdmans 1988) 478 who adds that Luke books passage as ship's doctor; R.J. Knowling, 'The Acts', EGT, (ed.) W.R. Nicoll (1901, rep. Grand Rapids, Eerdmans 1983) 2:515.

${ }^{23}$ So W.M. Ramsay, St. Paul the Traveller and Roman Citizen (London, Hodder and Stoughton 1895) 311. Cf. R.B. Rackham, The Acts of the Apostles (WC 41, 1913; 7th ed. London, Methuen 1951) 480 and W. Neil, The Acts of the Apostles (NCB 42, London, Oliphants/Greenwood, Attic 1973) 247, the latter considering it a serious possibility.

${ }^{24}$ So G. Stählin, Die Apostelgeschichte (NTD 5; 4th ed. Göttingen, Vandenhoeck und Ruprecht 1984) 314; L. Haefeli, 'Caesarea am Meer. Topographie und Geschichte der Stadt nach Josephus und Apostelgeschichte', NTAbh 10 (1923) 55.

${ }^{25}$ Aristarchus is a 'fellow prisoner' at Col. 4:10, but a 'fellow worker' at Phm. 24. Epaphras, on the other hand, is 'one of you and a servant of Christ Jesus' at Col. 4:13, but in Phm. 23 he is identified by Paul as 'my fellow prisoner'. 
mentioned at the end of verse 2. Third, Luke writes that Aristarchus 'was with us' (27:2). This associates him with Paul and the companion(s) of the 'we' source or more generally with the entire company embarking from Caesarea. The natural inference is that he stands in a looser relation to the others. $^{26}$ Finally, the assertion that Aristarchus accompanies Paul as a prisoner raises many unanswerable questions regarding his status and offence. ${ }^{27}$ The questions themselves further erode the notion that Aristarchus is a co-prisoner. He must, then, be accompanying Paul in some other capacity.

W.M. Ramsay has argued, "The minimum in the way of personal attendants that was allowable for a man of respectable position was two slaves; and, as we shall see, Paul was believed to be attended by two slaves to serve him' ${ }^{28}$ This idea and elements of the argument in support of it have considerable currency in modern treatments of the text. Ramsay continues: 'It is hardly possible to suppose that the prisoner's friends were allowed to accompany him $^{29}$ on the analogy of Pliny's account of the transport of the prisoner Paetus. We cite this text in its entirety:

Scribonianus had taken up arms in Illyria against Claudius [i.e., 42 AD)] but was slain. Paetus, who was of his party, was brought prisoner to Rome. When they were going to put him on board a ship, Arria besought the soldiers that she might be permitted to go with him: "Of course," said she, "you mean to give a consular, as he is, a few slaves to wait upon him at his table and toilet; but if you will take me, I alone will perform their whole duties." This favour, however, she could not obtain; upon which she hired a small fishing-vessel, and pursued that great ship in a mere cockleshell. ${ }^{30}$

According to Ramsay, 'The analogy shows how Luke and

${ }^{26}$ Cf. I.H. Marshall, The Acts of Apostles (TNTC 5; Grand Rapids, Eerdmans 1980) 404 and Bartlett, op. cit. 368 , who both suggest he may be on his way home by the same route as the others. Cf. Rackham, op. cit. 480 .

${ }^{27}$ If Aristarchus is a Roman citizen, has he, like Paul, been granted leave to have his case heard in Rome? If Aristarchus is not a Roman citizen, is he travelling as a condemned prisoner? Is he destined to serve out his life in one of many Imperial public works projects or to give his life as entertainment for the Roman populace at some sporting event?

${ }^{28}$ Ramsay, op. cit. 311 .

${ }^{29} \mathrm{Ibid}$. $315 \mathrm{f}$.

${ }^{30}$ Pliny, Ep. 3.16. 
Aristarchus accompanied Paul: they must have gone as his slaves, not merely performing the duties of slaves (as Arria offered to do), but actually passing as slaves' ${ }^{31}$

Ramsay continues ${ }^{32}$ that friends would hardly be permitted on such vessels as are indicated in Acts 27-28. The council held on board ship (27:11) shows the centurion to be the superior officer, thus confirming that the ship was a government vessel. The grain carriers that the centurion retained (27:6; 28:11) and that Rome so depended upon for its food supply, would hardly have been left to private enterprise. They are Imperial service vessels and, as such, the Authorized and Revised versions are hardly correct in translating

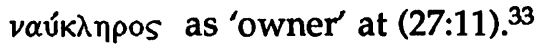

Against Ramsay, one cannot assume, first of all, that Paul would automatically be permitted slave attendants. Paetus' wife Arria is simply giving expression to a personal presumption based upon Paetus' consular rank. He probably gets his servants, though the text does not make this explicit. Other examples show that the privilege was not automatic, not even among royals. The son of Queen Roxanê $(316 \mathrm{BC})$ is denied the company of his pages in his confinement. ${ }^{34}$ The Jewish Prince Agrippa has freedman attendants but only because of the vigorous interventions of Antonia on his behalf. ${ }^{35}$ In addition, servants, if permitted, would probably have to be demonstrably, i.e., by virtue of documentation, members of the prisoner's domus. This could not be said of Luke or Aristarchus except by resort to a crude and unacceptable legal fiction which would certainly not have passed muster with the authorities. ${ }^{36}$

\footnotetext{
${ }^{31}$ Ramsay, op. cit. 316.

${ }^{32}$ Ibid. 323-5.

${ }^{33}$ So also NIV.

${ }^{34}$ Diodorus Siculus 19.52.4.

35Josephus, Ant. 18.204 [18.6.7]. J. Rougé, 'Actes 27, 1-10', VC 14 (1960) 202.

${ }^{36}$ It must be admitted that Paul is not adverse to the idea of having slave assistants (Phm. 11), warmly contemplating it in place of the master's help while in confinement (Phm. 13). Neither Luke nor Aristarchus, from what little we know of them, would be able to-or even want to-pass for slaves. The Macedonian Aristarchus, at the least, had a high ecclesiastical status in Thessalonica as he is one of the church delegates accompanying Paul to Jerusalem with the collection. Little is known of Luke. Distinguished as a gentile believer, he is identified as 'our dear friend Luke, the doctor' in Col. 4:14 and as one of the 'fellow workers' at Phm. 24. Cf. F.F. Bruce, The Acts of
} 
What of the notion that the ships used by Paul must have been part of the Imperial fleet? Dauvillier writes that while the Egyptian ships of the Ptolemies had been bequeathed to Augustus, it does not follow that all Alexandrian grain carriers plying the waters of the Mediterranean were the property of the Emperor. ${ }^{37}$ It is true, as Hemer writes, that Claudius, in response to the repeated difficulties of his time, 'developed the remarkable freighter-service from Alexandria to its peak of efficiency'. ${ }^{38} \mathrm{He}$ did this partly by encouraging the construction of ships-some of astonishing size. ${ }^{39}$ Other Claudian provisions, 40 however, suggest not only that there was a free-merchant service independent of the government, but that it furnished such a volume of grain as to be critical to the food supply needs of Rome. If grain carriage was solely a government-run operation, such inducements as Claudius employed to encourage risk-taking would hardly be necessary.

The first ship the centurion contracts for his party is probably not a government vessel, but from what 27:2 indicates of its port of origin and progress, it was a privately owned ship of the type of coastal trader known by the generic term oraria navis. ${ }^{41}$ It would be significantly smaller than the grain freighters tracking the open waters of the Mediterranean. ${ }^{42}$

Once the general command is given by the government

the Apostles (London, Tyndale 1952) $6 \mathrm{f}$.

37J. Dauvillier, 'A propos de la venue de saint Paul à Rome. Notes sur son procès et son voyage maritime', BLE 61 (1960) 20.

${ }^{38} \mathrm{C}$.J. Hemer, 'First Person Narrative in Acts 27-8', TynB 36 (1985) 88.

${ }^{39} \mathrm{Ibid.89}$. For Thasian port usage restrictions, and the granting of personal privileges and exemptions based upon ship tonnage, see L. Casson, Ships and Seamanship in The Ancient World (Princeton, PUP 1971), 171f. n. 23.

${ }^{40}$ Suetonius, $\mathrm{Cl}$. 18f., writes: '. . . he resorted to every possible means to bring grain to Rome, even in the winter season. To the merchants he held out the certainty of profit by assuming the expense of any loss that they might suffer from storms, and offered to those who build merchant ships large bounties, adapted to the conditions of each: to a citizen exemption from the lex Papia Poppaea; to a Latin the rights of Roman citizenship; to women the privileges allowed mothers of four children. And all these provisions are in force today'. By 'today' we should understand the period of Suetonius' life-i.e., c. 69-121 AD.

${ }^{41}$ Casson, op. cit. 337 n. 48 . For discussion of appointments and hire, see ibid. 337 n. 49; Pliny, Ep. 10.15; Ulpian in The Digest of Justinian, (ed.) Th. Mommsen and (tr.) A. Watson (Philadelphia, UPP 1985) [hereafter Dig.] 14.1.1.12.

${ }^{42}$ Casson, op. cit. 170-3 and 337. 
authorities at Caesarea to take Paul by sea to Rome, ${ }^{43}$ the details of travel are left entirely to the discretion of the centurion. The route arrangements are far from the type of 'military operation from first to last' which Ramsay suggests. ${ }^{44}$

Roman jurisprudence demanded considerable precision when it came to specifying ship's personnel. The shipowner proper is designated the dominus nauis (Dig. 14.1.1.15). Exercitor 'designates the person to whom all income and revenues come, even if he does not actually own the ship' ${ }^{45}$ The magister nauis is the director of the expetition who, if not himself also serving as exercitor, is appointed by the exercitor (Dig.14.1.1.2f.) and may stand in one of several possible relationships to him (Dig. 14.1.1.4). He is something more than the modern day supercargo in that he has charge 'of the whole ship' ${ }^{46} \mathrm{He}$ is 'appointed to hire out the ship for the carriage of cargo, to take on passengers, or to purchase provisions, or equipment. . $\therefore{ }^{47}$ The terms of the magister's appointment are usually specified in written contract and he can legally encumber the exercitor only if he stays within its terms. ${ }^{48}$

How does the vaúk $\lambda$ pos of 27:11 fit into this schema?

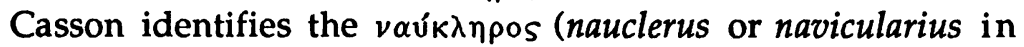
Latin) with the dominus or exercitor, and gives examples. ${ }^{49}$ Examples, however, can also be found where it means not 'owner' but something like expedition director. ${ }^{50}$ Its designation alone at 27:11 remains uncertain; it might mean owner, entrepreneur, or expedition director. Clearly, more information is needed. It is here that the centurion's role aboard ship is helpful.

All indications at 27:9-12 move one away from

\footnotetext{
${ }^{43}$ The centurion could have been ordered to take his prisoner by land and sea as seems to have been the case with Ignatius of Antioch (Ign. Rom. 5.1).

${ }^{44}$ See J. Rougé, op. cit. 193ff. who, aside from stating that the general command does not even specify the manner of conveyance, is correct that the route taken, the ports of call, and the speed of progress are all determined by meteorological and trading, rather than military considerations.

${ }^{45}$ Dig. 14.1.1.15.

46Ibid. 14.1.1.1.

${ }^{47}$ Ibid. 14.1.1.3.

${ }^{48}$ Ibid. 14.1.1.12. Cf. ibid. 14.1.1.2, 5.

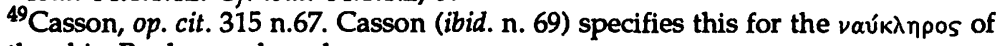
the ship Paul was aboard.

${ }^{50}$ E.g., P. Hib 1:39, 11. 5-7; P. Oxy 1:63.
} 


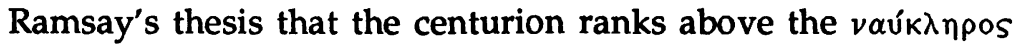
and $\kappa u \beta \epsilon \rho \nu \eta \dot{\tau} \eta s$ and has virtual command of the ship. We note, first of all, that the words, 'So Paul warned them, "Men,. . . ." (27:9f.) show Paul himself, rather than the centurion, convening the meeting. Moreover, his warning is general and not directed to the centurion alone. The apostle speaks from considerable personal experience, having known the favourable conditions of maritime travel (Acts passim) and having survived several disasters that attended unfavourable conditions (2 Cor.11:25f.). The person he must convince above all others is the $\kappa u \beta \in \rho \nu \eta$ ins (Latin gubernator), the steersman or pilot who has complete charge of the technical details of navigation. ${ }^{51}$ Paul may not be speaking out of turn-even as a prisoner. Seneca indicates that the more careful (cautior) pilot consults and attends the advice of those on ship who have maritime knowledge. ${ }^{52}$ Paul's advice, while not sought, nevertheless may carry some weight.

It is hardly possible to assert that the centurion is holding council when serious regard is taken of the words the

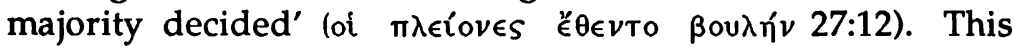
phrase could mean a majority of the ship's crew (Acts 27:11, 27, 30 ) or a majority of the 276 individuals aboard (27:37). ${ }^{53} \mathrm{~A}$ consilium on the example of $25: 12$, only furnishes advice to the one who makes the ultimate decision. It is not the centurion himself, but 'the majority', however construed, who decide.

Paul's 'advice', by implication, is that the cargo-laden vessel and its passengers and crew should proceed no further, but winter at Fair Havens. Both the $\kappa \cup \beta \in \rho \nu \eta^{\prime} \tau \eta s$ and the vaúk $\lambda$ pos apparently concur with Paul in regard to wintering on Crete. However, they (and particularly the vaúk $\lambda$ pos as owner or operator) are concerned that the grain ship might be damaged in the exposed harbour. They wish to make for the more suitable harbour $\mathbf{4 0}$ miles further up coast at Phoenix.

What, then, do the words, 'But the centurion, instead of listening to what Paul said, followed the advice of the pilot

${ }^{51}$ Dauvillier op. cit. 15. Cf. Dig. 19.2.13.2 .

${ }^{52}$ Seneca, Ep. ad Lucilium 14.8.

${ }^{53}$ So G. Schneider, Die Apostelgeschichte (HTKNT 5/2, Freiburg, Herder 1982) 390. Cf. the progress of Herod and his retinue by ship from Brundisium to Alexandria as described in Philo, In Flaccum 5.26f. 
and of the owner of the ship' (verse 11) mean? The possibilities available to the centurion appear to be these: he might listen to Paul and either (a) elect to remove his party from the ship and contract a carrier in the safe season, or (b) try to convince the other passengers and the crew on the ship that they should winter in Fair Havens. Alternately, he might listen to the $\nu \alpha u ́ k \lambda \eta \rho \circ$ and $\kappa u \beta \epsilon \rho \nu \eta \dot{\tau} \eta s$ and vote to proceed to the harbour at Phoenix. He comes down on the side of the expertise of the $\kappa u \beta \in \rho \nu \eta \dot{\tau} \eta s$ and $\nu \alpha u ́ k \lambda \eta \rho \circ$; so, in consequence, must his party. The centurion would have had no choice but to winter in Fair Havens if these men had fully concurred with Paul..$^{54}$

One cannot salvage the centurion's command of the ship by reference to his involvements at the point of shipwreck. It would be an exaggeration to say, when the centurion (on Paul's advice!) prevents the flight of the sailors by having the lifeboat cut away (27:30-2) and later co-ordinates an orderly abandonment of the foundering ship (27:43f.), that he is in charge.

The deliberations and actions of Acts 27 do not show the centurion to be the commander of the ship. He is a single voice speaking on behalf of a party of individuals over whom he has charge. The 'surprising influence of the centurion upon the authority of the professionals ${ }^{\prime 55}$ which some see is simply not to be found.

In what capacity do Luke and Aristarchus accompany Paul? They would be accompanying him as friends in Roman eyes; as religious associates in their own eyes. At Acts 24:23 Felix grants Paul the privilege of being attended to by 'his friends'. Nothing in the intervening text suggests that circumstances have changed. Special permission may have had to be formally granted to these friends to travel with Paul as a larger party may have caused difficulties when the centurion was contracting passage. Taking commercial vessels, they would conduct themselves as fare-paying passengers. Ramsay suggests that if Paul was perceived to have personal slaves seeing to his needs on the voyage, 'his importance in the eyes of

${ }^{54}$ So Dauvillier, op. cit. 21.

${ }^{55}$ Hemer, op. cit. 94. 
the centurion was much enhanced'.56 Attended by non-slave friends, however, his importance should be all the greater.

3. Churches: The prisoner Paul is shown to receive considerable help from churches in the book of Acts. Of particular concern, however, is the meeting he has with the Roman Christians on the way to Rome. While Paul is staying with the Christians of Puteoli, word is sent to the believers in Rome that he is on his way. Coming down from Rome as far as Three Taverns and the Forum of Appius, a group identified as of $\dot{\alpha} \delta \in \lambda \phi$ oi $(24: 15)$ meet the prisoner apostle. Most scholars specify these individuals very generally as, a 'group' or 'number' of Christians,, ${ }^{57}$ Hervey in particular likens them to the diffuse Jewish group that met the pretender Alexander as he made his way to Rome. ${ }^{58}$ Have they correctly identified these individuals? The evidence seems to suggest not.

Rendering assistance to the prisoner is identified as a virtue in the NT and its practice is incumbent upon all Christians. Evidence suggests that from a very early point such church help was structured. Lucian's description of the imprisonment of Peregrinus (c. 132-4 AD), ${ }^{59}$ affords some insight into how help was given locally. He writes that, 'from the very break of day aged widows and orphan children could be seen waiting near the prison, while their officials even slept inside with him'.60

Why widows and orphans are present is not indicated by Lucian. Krauss avers that the widows are present in the official capacity of deaconesses. ${ }^{61}$ It is much more likely, however, that their official title is in fact, 'widow'.

\footnotetext{
${ }^{56}$ Ramsay, op. cit. 316.

${ }^{57}$ So, e.g., Stählin, op. cit. 475; R.N. Longenecker, 'The Acts', EB Commentary, (ed.) F.E. Gaebelein (Grand Rapids, Zondervan 1981) 9:568; Bruce, Book of Acts 502.

${ }^{58}$ A.C. Hervey, The Acts of the Apostles (Pulpit Commentary 2; London, Kegan Paul, Trench 1884) 322 cites Josephus, Ant. 17.330 [17.12.1]: 'So when the report about him reached as far as Rome, the whole Jewish population there [ $\tau \grave{\text { ò }} \mathrm{T} \hat{\eta} \delta \epsilon$

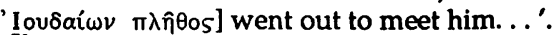

${ }^{59}$ See G. Bagnani, 'Peregrinus Proteus and the Christians', Historia 4 (1955) 112. Bagnani's article helpfully describes Peregrinus' 'Christian period'.

${ }^{60}$ Lucian, Peregr. 12.

${ }^{61}$ F.A.K. Kraus, Im Kerker Vor und Nach Christus: Schatten und Licht Aus d. profanen und Kirchl. Culture $=u$. Rechtsleben vergang. Zeiten. In 3 Büchern (Tübingen, Mohr 1897) 92.
} 
Qualifications for enrolment of widows on the official church support list according to 1 Timothy 5:9f. included being 'over sixty' and being known for such good deeds as 'helping those in trouble ${ }^{\prime 62}$ and 'bringing up children' ${ }^{63}$ This would account for the presence of aged widows at the prison as well as that of the orphans.

Who are the 'officials' Lucian mentions? Clearly, they must be local church leaders of some sort. Several possibilities are suggested by the Christian martyr literature. There we find bishops, deacons, sub-deacons and catechumens in attendance upon the imprisoned confessors. ${ }^{64}$ This pattern of local assistance through church officials may represent a later adaptation of the poor relief pattern of the Jerusalem church. There, individual believers gave their resources into the charge of the apostles (Acts 4:34, 36f.; 5:lf.) who in turn disbursed them amongst the needy - at first directly (6:lf.), then later through specially qualified surrogates $(6: 3-6){ }^{65}$

This structure in helping-i.e., church members donate; church leaders visit and disburse help-is even more clearly indicated where churches come to the prisoner from a distance. Ignatius writes to the Trallians that their Bishop Polybius has visited him in Smyrna: 'I received therefore your godly benevolence through him' ${ }^{66} \mathrm{He}$ asserts that he has received the entire Ephesian congregation in the person of their Bishop Onesimus. ${ }^{67}$ The Ephesian deacon Burrhus is also sent; appar-

\footnotetext{
${ }^{62}$ The assistance rendered would be of a material nature (cf. 1 Tim. 5:16). G. Holtz, Die Pastoralbriefe (Berlin, Evangelische Verlagsanstalt 1971) 118, suggests that the $\theta \lambda_{\imath} \beta$ ó $_{\mu \in v o s}$ is one whose life has been touched by death, serious illness, great material loss, or persecution. Cf. B.M. Rapske, The Widow in the Apostolic Church (Vancouver, Unpublished MTh Dissertation 1987) 209.

${ }^{63}$ The widows here noted are sixty years of age and have not remarried after the death of their spouses. Moreover, they can get no support from children or grandchildren as they are all alone. The objects of their child-rearing are therefore orphans. Cf. Rapske, op. cit. 207.

${ }^{64}$ E.g., Mart. Perp. E Felic. 3.7 (deacons); Mart. Mont. \& Luc. 9.2 (bishop, subdeacon and catechumen); Apostolic Constitutions [ANF 17] 5.1.1 (bishop).

${ }^{65}$ The Jerusalem church pattern of help itself is a development of Jewish poor relief through the 'basket' (תמהזהי) (קָּה). For further discussion see Rapske, op. cit. 170-3.

66Ign. Trall. 1:2.

67Ign. Eph. 2:1. The same is said to the Magnesians of their bishop Damas, the presbyters Bassus and Apollonius, and also to the deacon Zotion at Ign. Magn. 2.
} 
ently with instructions from his church as to how long he may stay. ${ }^{68}$ This same Burrhus is identified to the Philadelphian church as 'sent with me by the Ephesians and Smyrnaeans as a mark of honour' ${ }^{69}$ The non-Christian Lucian also mentions this pattern of concerted church help at a distance in aid of Peregrinus, without mentioning the titles of the individuals in these deputations: 'Indeed people came even from the cities in Asia, sent by the Christians at their common expense, to succour and defend and encourage the hero' ${ }^{70}$

4. The Brothers from Rome and Paul: Ellis has argued that, "when used in the plural with an article, "the brothers" in Pauline literature fairly consistently refers to a relatively limited group of workers, some of whom have the Christian mission and/or ministry as their primary occupation' ${ }^{71} \mathrm{He}$ continues that this can also be shown for Acts. The designation of $\dot{\alpha} \delta \in \lambda \phi$ of (1) depicts travel companions, sometimes distinguishing them from disciples generally, ${ }^{72}(2)$ indicates the letterbearing envoys to the Jewish community in Rome', ${ }^{73}$ and (3) sets apart individuals in local churches from the general body of believers, at times associating them with the church's leadership. ${ }^{74}$ While Ellis places our group in category $(1)^{75}$ owing to the fact that they accompany Paul en route to Rome, they more properly belong to category (3).

The structure of help and companionship seen in the experiences of Ignatius, Peregrinus and the later confessors adds to the conviction that these 'brothers' are the leaders of the church in Rome. Word is sent to the Roman church at a distance that the apostle is on his way. In conformity with the pattern, these officials come, either at the behest of their congrega-

\footnotetext{
${ }^{68}$ Ign. Eph. 2:1. This text indicates that other church representatives (oiz., Crocus, Euplus and Fronto) are in Ignatius' company. These are mentioned once again in Ign. Rom. 10:1.

${ }^{69}$ Ign. Phld. 11:2.

${ }^{70}$ Lucian, Peregr. 13.

${ }^{71}$ E.E. Ellis, 'Paul and His Co-Workers', NTS 17 (1970-1) 446f. Passages leading him to this conclusion are 2 Cor. 8:18f., $23 ; 9: 3,5 ; 11: 9 ; 12: 18$; 1 Cor. 16:10ff. and, particularly, 1 Cor. 16:19f.; Eph. 6:23f.; Phm. 4:21f. and Col. 4:15.

72 Ellis, op. cit. 447 discusses Acts 9:26f., 30. See his n. 3 for additional examples.

${ }^{73}$ See ibid. 447 and his $n .4$ for discussion of Acts 28:21.

${ }^{74} \mathrm{Ibid}$. 447 and his nn. 5-7 where he discusses Acts 11:1; 12:17; 14:2; 15:23; 16:1f., $27 ; 21: 17 ; 22: 5$.

${ }^{75}$ Ibid. 447.
} 
tion(s) or leaders or of their own accord. We may add that 28:15 carries additional evidence, increasing confidence that these brothers are not just a rag tag crowd but rather a formal ecclesiastical escort. Bruce writes:

$\alpha \pi a ́ v \tau \eta \sigma \imath s$ [meeting] was almost a technical term for the official welcome of a visiting dignitary by a deputation which went out from the city to greet him and escort him for the last part of his journey; cf. the same use in Mt. 25:6; 1 Thes, 4:17 (also Cicero, Letters to Atticus 8.16.2; 16.11.6). ${ }^{76}$

\section{Gaining Access to the Prisoner.}

Clement of Rome, in encouraging expressions of love to those in distress, asserts: 'so far as you can, help those in prison. . .'77 The implication is that Christian help might be hobbled or blocked entirely by the external constraints of prison regimens and personnel. These limitations are also relevant to the Pauline experience in such places as Philippi and Rome.

1. Prison Regimens. The outer prison gate or door was the point at which family and/or friends had to break company with the prisoner. ${ }^{78}$ Helpers came there to plead for the opportunity to see the prisoner. ${ }^{79}$ There, too, helpers might await its opening at daybreak, ${ }^{80}$ or even camp near it when it was closed during the night. ${ }^{81}$

Extra-biblical sources suggest that normally, visits were permitted only in the daylight hours. A passage in Lucian's Toxaris affords a helpful indication of the typical pattern. When Demetrius of Sunium heard of his friend's incar-

\footnotetext{
${ }^{76}$ Bruce, Book of Acts 502.

${ }^{77}$ Clementine Homilies (ANF 17) 3.69 [My italics.] Cf. Apostolic Constitutions 5.1.1.

${ }^{78}$ F. Oehler, (ed.) Quinti Septimii Florentis Tertulliani Quae Supersunt Omnia, Tomus 1 (Lipsiae, T.O. Weigel 1853) Tertullian, Ad Mart. 2 (On Fasting 12 [ANF 11]); Mart. Mont. \& Luc. 17.1f.

${ }^{79}$ Cicero, Ver. 2.5.118: 'The fathers-you see them here in court-lay crouched in the doorway; the unhappy mothers passed the nights at the prison entrance, cut off from the last sight of their children, begging for nothing but permission to receive with their lips their son's parting breath'. Cf. Lucian, Tox. 30; Achilles Tatius, Leucippe \& Clitophon 6.14.1f.

${ }^{80}$ Supra n. 60.

${ }^{81}$ Cf. Cicero, supra n. 79. According to Lucian, Tox. 31, Demetrius, 'slept just in front of the prison door, where he had made a place to lie and had put down some leaves'.
} 
ceration, he rushed to the prison: 'At that time, however, he was not admitted, for it was evening and the keeper had long ago locked the door and gone to sleep, after directing his servants to keep watch. . ${ }^{82} \mathrm{He}$ is only able to gain entry in the morning. It is to be doubted that those helping the Jewish Prince Agrippa were permitted to stay with him through the night in the praetorian camp at Rome, ${ }^{83}$ and the witness of the NT Apocrypha and Christian martyr literature also confirms this pattern. ${ }^{84}$ Night visits constituted a risk to the security of the prison, but access to the prisoner could, if at all, be gained by means of bribery. ${ }^{85}$

2. Prison Personnel. Discretion in regulating access to visitors and helpers was usually left in the hands of prison personnel. Access might be relatively easy, ${ }^{86}$ particularly if the prisoner was under house arrest. ${ }^{87}$ Even so, prison security was always a matter of concern and the most relaxed conditions could instantly be staunched. ${ }^{88}$ Cyprian (c. 248 AD) warns that prison

\footnotetext{
${ }^{82}$ Lucian, Tox. 30. Demetrius' pattern is to work as a stevedore from very early in the morning until noon. He then spends the afternoon with Antiphilus until evening when the prison is closed to visitors (Ibid. 31). See Plutarch, Moralia: de genio Socratis $598 \mathrm{~A}, \mathrm{~B}$ on evening time as an 'unusual hour' for officials to take action regarding prisoners. Achilles Tatius, Leucippe and Clitophon 6.15. ${ }^{83}$ Josephus, Ant. 18.204 [18.6.7] suggests that they were permitted visits. That there is much connivance in the provision of clothes for Agrippa's bedding suggests that the soldiery of the praetorium where Agrippa was held, were generally hostile to him. Allowing the freedmen or friends to stay overnight would hardly have been possible in such a generally hostile environment.

${ }^{84}$ In the Apoc. Acts of Thomas 13.154, Vazan is unable to go to Thomas at night 'for the gaolers have shut them [i.e., the doors] and gone to sleep'. The jailers later indicate, ' . . we shut the doors at the proper time . . $\therefore$ (Ibid. 13.162). Concern for the presence of visitors and lit lamps in the prison suggests that rules have been violated. (Ibid. 13.153). Mart. Mont. \& Luc. 4.7: 'The consolation and the joy of the day [i.e., of brothers' visits] removed all the agony we endured at night'. Mart. Mar. $\&$ James 6.4: 'Dedicated as they are to God the Father, their brothers care for them by day, Christ by night as well'.

${ }^{85}$ The mother of Furius must certainly have bribed the prison staff in order to be with her condemned son 'day and night'. (Cicero, Ver. 2.5.112; cf. 2.5.118). Lucian, Peregr. 12, speaks of how the Christians' 'officials even slept inside [i.e., the prison] with him after bribing the guards'. For access at night by bribery, see also Apoc. Acts of Thomas 9.118 (the bribe is ten denarii); 13.151 (363 staters); Apoc. Acts of Paul 3.18 (a silver mirror).

${ }^{86}$ Cyprian, Ep. 4.2 [ANF I].

${ }^{87}$ Tertullian, de Ieiunio 12 (English = On Fasting 12 [ANF 18]).

${ }^{88}$ Lucian, Tox. 32, writes that when a brigand 'died in the prison (by poison, it was thought) a close guard was instituted, and not one of those who sought admission could enter the gaol any longer'.
} 
visitors be few in number and always changing. Such careful management by the local church leadership would prevent suspicion, ill-will and the risk of being denied access. ${ }^{89}$

Access could, however, be very difficult. The Christian Lucian is commended by Montanus and Lucius in that he 'pierced the most stubborn obstacle of our imprisonment' ${ }^{90}$ While officials were open to the entreaties of the helper, ${ }^{91}$ and could give access out of pity or respect for the prisoner,, 92 a frequent means of gaining entry to the prisoner was by bribery. As we have seen, bribery could give access to the prisoner at night. It was often as necessary during the day-time. Cicero writes how the prison warder and lictor Sextus sold access as a privilege: '.. every groan and pang meant a scheduled profit for him. "So much for leave to see him [i.e., the prisoner]-so much to be allowed to bring in food and clothing"-and everyone paid up $^{\prime} .{ }^{93}$ Philostratus records how, after Apollonius had been in prison two days, a stranger came to him 'and said that he had purchased the right to visit him'. ${ }^{94}$ Such bribes could be either in $\operatorname{cash}^{95}$ or in kind. ${ }^{96}$ Failure to have regard for the itchy palms of prison officials might result both in hardship for the prisoner and denial of access for the helper. ${ }^{97}$ The practice of bribery was common enough that it is recorded as part of the expense of relief in the Apostolic Constitutions (3rd century AD): the Christian is encouraged to 'send to him [i.e., the prisoner] from your labour and your very sweat for his sustenance, and for a reward to the soldiers, that he may be eased and be taken care of ${ }^{\prime} .98$

\footnotetext{
${ }^{89}$ Cyprian, Ep. 4.2.

${ }^{90}$ Mart. Mont. \& Luc. 9.2.

${ }^{91}$ Lucian, Tox. 30.

${ }^{92}$ Mart. Perp. E Felic. 9. Cf. Mart Pion. 11.5-7.

${ }^{93}$ Cicero, Ver. 2.5.118.

94 Philostratus, VA 7.30.

${ }^{95}$ Lucian, Tox. 31 and supra n. 85.
}

${ }^{96}$ Mart. Pion. 11.4; Talm. Mo'ed III: 'Erub 21b; infra n. 97.

${ }^{97}$ Mart. Pion. 11.3f. Denied their share of incoming goods when the Christian prisoners refuse the helpers' generosity, the guards angrily throw them into the

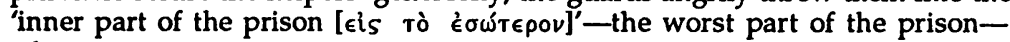
where no one can visit.

${ }^{98}$ Apostolic Constitutions 5.1.1. G. Lopuszanski, 'Police Romaine et les Chrétiens, Antiquité Classique 20 (1951) 39, identifies this as bribery to obtain entry to the prisoners. 
3. Paul in Philippi and Rome. While access to the prisoner Paul in Acts generally, seems to have been easy, this cannot be said of his experience at Philippi. There is, in fact, no access from without the prison; not from associates nor from new converts. Several factors account for this: First, the imprisonment of Paul and Silas seems to be punitive and entirely uninformed by the fact of the missionaries' status as Roman citizens (16:37f.). Permission to have visitors or helpers would have constituted a mitigation of the punishment. Second, the jailer is commanded to 'guard them safely' (16:23), which he effects by putting them 'in the inner cell and ... their feet in the

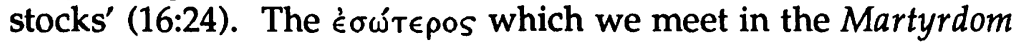
of Pionius ${ }^{99}$ amounts to a kind of isolation cell for solitary confinement. Added to this, the prison, as we have seen, could be barred to visitors at night-fall (cf. 16:24f.). The closest that the apostles' associates or converts might get at any time during their night of incarceration would be the outer gate or door of the prison. (Would Luke have 'camped out' near the door?) Denied from without, however, help comes from within by the hand of the jailer and his family.

What can be gathered of Paul's confinement for two years in Rome (28:16ff.) suggests a fairly generous degree of access. Sadler's insistance that Paul must have been able to 'go anywhere, provided he had the permission of the captain of the guard, who, of course, would require that the soldier to whom he was chained should accompany him', ${ }^{100}$ does not have sufficient regard to the evidence in the text. It indicates that individuals and groups are able to come to Paul, apparently without restriction. The progression in the record of visits to Paul suggests increasing freedom of access and increasing numbers of visitors: First, Rome's Jewish leaders come to Paul $(28: 17,20)$, return for a second meeting 'in even larger numbers' (28:23); finally, 'all' (28:30) who wish can have access to him.

Though Acts predicates to Paul the activity of inviting these individuals $(28: 17,20,23)$, the invitations must certainly have been extended through others; viz., the Roman

\footnotetext{
${ }^{99}$ Supra n. 97.

${ }^{100}$ M.F. Sadler, The Acts of the Apostles With Notes Critical and Practical (1887; rpt. London, G. Bell and Sons 1910) 501.
} 
Christians. ${ }^{101}$ Paul's confinement in an individual dwelling is emphasized at several places in the text. ${ }^{102} \mathrm{He}$ can welcome individuals and groups into his living quarters $(\dot{\alpha} \pi \epsilon \delta \epsilon \in \in T 0$

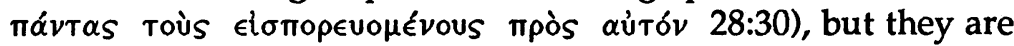
not permitted actually to live with him. The regimen previously described seems here to be implied-i.e., free access to the prisoner during the day; enforced solitude through the night. This would afford, from the authorities' perspective, sufficient freedom for the prisoner, yet without threat to security. Paul utilizes this regimen to the maximum on the second occasion of the Jews' meeting with him when he speaks 'from morning till evening' (28:23). Evening having come and having reached an impasse in the debate, those present eventually leave Paul (28:25); presumably alone with the soldier.

The final word of Acts, which Moulton and Milligan describe as legal to the last', ${ }^{103}$ may also be taken to have something to say regarding the degree of access allowed the imprisoned apostle as well as the amount of assistance that helpers could give. The NT hapax legomenon 'unhindered' ( $\alpha \kappa \omega \lambda u ́ \tau \omega s$ 28:31) suggests the tolerance of Rome generally. ${ }^{104}$ We would agree with Stählin in adding that it probably also has an eye to the ever-present individual soldiers ${ }^{105}$ who guarded the apostle during the years in Rome.

\section{Encouraging the Prisoner}

1. Emotional Help: Prison was a place not only of physical suffering, but a place of profound anxiety for the stresses it brought to the prisoner. In such a context, the physical presence and verbal encouragements of helpers could be a great boost emo-

${ }^{101}$ We should not expect that Paul's companions-the 'we' of the travel narrative-would have sufficient information as to issue invitations to the leaders of the Jewish synagogues.

${ }_{102}$ Acts 28:16,23,30.

${ }^{103} \mathrm{~J} . \mathrm{H}$. Moulton and G. Milligan, The Vocabulary of the Greek Testament Illustrated from the Papyri and Other Non-Literary Sources (London, Hodder and Stoughton 1930) 20.

${ }^{104} \mathrm{E}$. Haenchen, The Acts of the Apostles: A Commentary, (tr). B. Noble et al. (Oxford, Basil Blackwell 1971) 726; Longenecker, op. cit. 573; H.J. Hauser, Strukturen der Abschlusserzählung der Apostelgeschichte (Apg 28,16-31) (AnBib 86; Rome, Pontifical Biblical Institute 1979) 141.

${ }^{105}$ Stählin, op. cit. 329. 
tionally to the prisoner. We have already mentioned the friends of Publius Vitellins (31 AD) who, when they discover that he has opened his veins, are able to convince him of the value of continuing life in custody. He consents to be bandaged and restored and dies a natural death while in confinement. ${ }^{106}$ Lucian's praise of true friendship emphasizes quite vigorously the virtues of physical closeness and verbal encouragement. Agathocles is praised for standing with his friend Deinias: 'Agathocles alone of all his friends kept with him, sailed with him to Italy, went to the trial with him, and failed him in nothing'. ${ }^{107}$ When Deinias was sentenced to exile, Agathocles 'did not desert his comrade even then, but of his own accord sentenced himself to live in Gyaros and share his exile'. ${ }^{108}$ Demetrius of Sunium, as a part of his daily pattern, remains with Antiphilus in the prison, keeping him in heart $\pi \alpha \rho \alpha \mu v \theta \alpha \dot{\alpha} \mu \nu \nu{ }^{\circ} .{ }^{109}$ When denied the usual access, Demetrius implicates himself in his friend's alleged crime and begs, on being cast into prison, to be 'confined near Antiphilus, and in the same set of irons. ${ }^{110}$

The Christian martyr literature also carries such emphases. The verb refrigerare which often means 'to make cool', can also have the sense of comforting, relieving, or refreshing. ${ }^{111}$ In some contexts, the refreshment consists in comestibles and such. ${ }^{112}$ Other contexts, however, suggest that the refreshment has a more general character which includes emotional consolation. The adjutant in charge of the prison in which Perpetua and Felicitas, are lodged (203 AD), 'began to

\footnotetext{
${ }^{106}$ Suetonius, Vit. 7.2.3.

${ }^{107}$ Lucian, Tox. 18. Note the many ouv-compounds in the original.

${ }^{108} \mathrm{Ibid}$. Note again the ouv-compound.

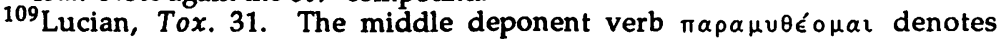
encouragement or cheering up, particularly in connection with bereavement or some other tragic event according to $\mathrm{BAGD}^{2} 620$. In our context, the consolation is extended to the one who is in shock or depression because of incarceration. Cf.

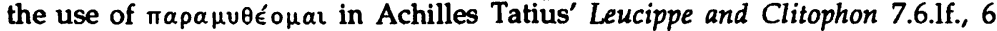
where friends comfort the imprisoned protagonist who has resolved to commit suicide.

${ }^{110}$ Lucian, Tox. 32.

${ }^{111}$ C.T. Lewis and C. Short, A Latin Dictionary (1879; rpt. Oxford, Clarendon 1962) 1548. The related term refrigerium can mean 'a rest, relief' according to the Oxford Latin Dictionary (ed.) P.G.W. Glare (Oxford, Clarendon 1982) 1597. ${ }^{112}$ E.g. Mart. Mont. \& Luc. 9.2; Mart. Perp. \& Felic. 16.3.
} 
allow many visitors to see us for our mutual comfort'. ${ }^{113}$ The account of Montanus and Lucius (259 AD) records: 'For a few days then we were comforted by the visits of our brethren. The consolation and the joy of the day removed all the agony we endured at night ${ }^{114}$ The brothers, on hearing of the imprisonment of bishop Fructuosus (259 AD), are 'with him, comforting him and begging him, to remember them'. ${ }^{115}$

W. von Dobschütz helpfully summarizes the Ignatian material in this regard:

He [i.e., Ignatius] rejoices at their escort (Phil. xi., Smyr. xii.); hurrying on before by the direct road, the Ephesians go to Rome on his behalf (Rom. $x$ ). He knows that the nearer Churches have already sent deputations, and is convinced that the people of Asia Minor can do so also-for the name of God (Phil. $x$ ). Who is ready to assist those who desire to do well (Smyr. xi. 3); the Christian does not belong to himself; he must have time for God (Polyc. vii. 3). As a matter of fact we see that the Philippians, the most remote, have asked the Smyrnaeans to represent them also, and Polycarp, either himself or through a deputation, will on a favourable opportunity make the due arrangements (Polyc. ad Phil. xiii). ${ }^{116}$

It is important to Ignatius that the churches show solidarity with him and, when it comes, his sense of appreciation is expressed effusively. Where possible, physical solidarity must be shown. Less desirable but still acceptable are solidarity expressed through nominated proxies or by means of epistles. Most importantly, however, the solidarity must be formal and official, i.e., the representatives must be bishops, deacons, or other approved church officials and they must be sent by their churches and leaders.

2. The Brothers from Rome and Paul. It is to be presumed that Paul derived considerable encouragement from the physical presence of helpers during the confinements at various locations described in the book of Acts. He would have certainly been heartened by the assistance and company of associates, particularly those of the 'we' source and the Thessalonian church offi-

${ }^{113}$ Mart. Perp. E Felic. 9.1.

${ }^{114}$ Mart. Mont. \& Luc. 4.7.

${ }^{115}$ Mart. Fruct. \& Co. 1.4 .

${ }^{116} \mathrm{~W}$. von Dobschütz, Christian Life in the Primitive Church (Theological Translation Library 18; London, Williams and Norgate 1904) 241. 
cial Aristarchus who accompanied him as he journeyed to Rome. Paul would have counted as a rich blessing the centurion's permissions to solicit benefactions and accept the hospitality of Christian groups along the way to Rome. ${ }^{117}$

Of particular interest to us, however, is what is said concerning the meeting of Paul and 'the brothers' (28:15). When he saw them, Luke records, Paul thanked God and was encour-

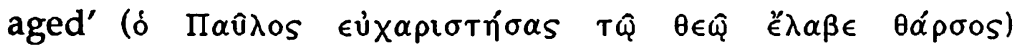
Ramsay states that this phrase must be taken as an indication of 'some marked frame of mind. We have already observed him in a similar state of depression when he was in Troas and Philippi' ${ }^{118}$ Yet depression is hardly the emotional state one would expect before the taking of courage. Rather, as the term $\theta \alpha \dot{\rho} \sigma o s$ in other contexts suggests, ${ }^{119}$ we should expect fear and anxiety to be the logically preceding emotional states.

Coming to Rome as a prisoner, one of Paul's worst fears is to be damned by the faint support of the Christian community there. Paul's vigorous reaction is motivated not only by the presence of $\dot{\alpha} \delta \in \lambda \phi o i$, but even more so by their identity. As we have previously indicated they are church leaders. In terms of the Ignatian experience, they are an encouragement not only because they show physical solidarity with the prisoner, but more so because they come to Paul formally and officially. They are, pars pro toto, the Roman church. Longenecker remarks that the expression of gratitude to God is specially mentioned by Luke because of its unusual fervency. ${ }^{120}$ We might add that Luke may have also been motivated to include this exuberant response as the logical concomitant to the discovery that the church of Rome stood with Paul in his predicament.

\section{The Risks to the Helper}

Helping the prisoner could pose significant threats to the safety and well-being of the helper. Officials were often very

${ }^{117}$ D.O. Bauernfeind, Kommentar und Studien zur Apostelgeschichte (WUNT, 22: 1933; rv. com. Tübingen, Mohr 1980) 273, perceptively remarks concerning Acts 27:3, Wie lange ist es her, seit Paulus zum letztenmal eine Gmde besucht hat!'

${ }_{118}$ Ramsay, op. cit. 347.

${ }^{119}$ See the context of Acts 23:11; Josephus, Ant. 9.55 [9.4.3]; Mart. Pol. 12.1; Herm. Vis. 3.1.5.

${ }^{120}$ Longenecker, op. cit. 568 . 
rough characters. Consequently, helpers might be harassed out of a desire for personal gain or even for sport. The Egyptian cultivator from Karanis (c. 3rd century BC) complains that the policeman Hathoris has confiscated not only bread destined for the relief of a prisoner at the great prison of Crocodilopolis but also the cultivator's own jenny. He continues, 'I made myself scarce for fear of being marched to prison' ${ }^{121}$ On one occasion when Rabbi Joshua was bringing a water ration to Rabbi Akiba (132-5 AD), he was stopped by the prison keeper who said to him, "Your water to-day is rather much; do you perhaps require it for undermining the prison?" He poured out a half of it and handed to him the other half' ${ }^{122}$ The part water ration was only enough for Akiba to perform the ritual hand washing before eating. He did not, after that, have water enough to drink. Here we have a clear case of bullying.

There was the additional danger of simply being too intimately associated with or sympathetic toward the prisoner or his views. The relatives of imprisoned royals were in a precarious position. ${ }^{123}$ Fearing imprisonment and death should they follow their teacher to Rome (c. 54-68 AD), the number of Apollonius' disciples is reduced from thirty-four to eight. ${ }^{124}$

The helpers of the Christian confessors found that when they applied themselves zealously to care-giving, the personal risks were greater. Workman states that 'visits were allowed, possibly as the easiest way whereby the authorities could learn the names of others of the faith still at large' ${ }^{125}$ Origen (184/5-253/4 AD), when visiting prisoners, exposed

${ }^{121}$ E.G. Turner and W.E.W. Cockle, 'Complaint Against a Policeman', JEA 68

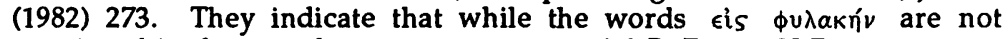

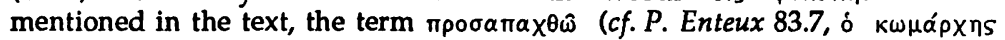

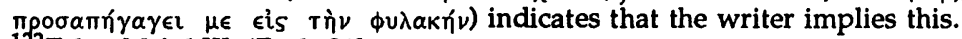

${ }^{122}$ Talm. Mo'ed III: 'Erub. $21 b$.

${ }^{123}$ Plutarch, Lives: Agis and Cleom. 20.2-5 on the fate of King Agis and his family.

${ }^{124}$ Philostratus, VA 4.37: 'And in fact the knock-kneed among them were detected in no time, for under the influence of what Philolaus said, some of them declared that they were ill, others that they had no provisions for the journey, others that they were homesick, others that they had been deterred by dreams; and in the result the thirty-four companions of Apollonius who were willing to accompany him to Rome were reduced to eight'.

${ }^{125}$ H.B. Workman, Persecution in the Early Church: $A$ Chapter in the History of Renunciation (London, Charles H. Kelly 1906) 293. 
himself to personal danger when he, with extreme boldness, saluted the imprisoned confessors with the holy kiss. ${ }^{126}$ When Agapius and Dionysius attended to the needs of six Christian prisoners (309-10 AD), they did so with such assiduity that it attracted the attention of the officials who ordered their arrest. All eight were subsequently condemned and beheaded. ${ }^{127}$

There were many watchful eyes and listening ears in prisons. A chance word or act might lead not only to the prisoner's but also the helper's doom. Musonius and Apollonius did not converse directly to one another during the time that the former was imprisoned (Nero 54-68 AD) because Musonius declined to do so, in order that both their lives might not be endangered'. ${ }^{128}$ Later, when Apollonius himself is imprisoned by Domitian (81-96 AD), spies are sent to him. One enters the prison in the guise of a fellow prisoner: 'In his deportment this person had a downcast air, and, as he himself admitted, looked as if he ran a great risk. He had great volubility of speech, as is usually the case with sycophants who have been chosen to draw up eight or ten informations'.$^{129}$ Later, a visitor comes to Apollonius for the ostensible purpose of helping him out of his predicament., Actually, his hope is (1) that Apollonius, 'out of sheer weariness of his imprisonment. . .would tell some falsehood to the detriment of his friends' ${ }^{130}$ or (2) 'to see whether he would reproach his sovereign on account of his sufferings' ${ }^{131}$

Several strategies might be used to reduce the risks and dangers to the helper. First, the helper might resort to disguise. Apollonius advises his disciple/helper Damis, ${ }^{132}$

I do not wish that you should be a sharer of my fate through being detected by your dress, which will certainly betray you and lead to your arrest; but I would rather that you followed me in the guise of one not sworn to my philosophy, but just attached to me for the other reasons.

${ }^{126}$ D.W. Riddle, The Martyrs: A Study in Social Control (Chicago, CUP 1931) 69f., citing Eusebius, HE 6.6.3f.

${ }^{127}$ A.J. Mason, The Historic Martyrs of the Primitive Church (London, Longmans Green 1905) 288f. citing Eusebius, De mart. Palaest. 3.

${ }_{128}$ Philostratus, $V A 4.46$.

${ }^{129}$ Ibid. 7.28.

${ }^{130}$ Ibid. 7.36 .

131 Ibid.

${ }^{132}$ Ibid. 7.15 . 
The Talmud recounts a vision which illustrates the advantages of such a strategy. The prophet Elijah comes to Rabbi Beroka Hoza'ah and identifies to him a man who will share in the world to come. Beroka is surprised by the fact that the man is a jailer and appears not to be a Jew: he sports no distinctive Jewish tassles on his clothing and wears the latcheted black shoes common to Gentiles. When asked, the jailer explains that he does this 'that the Gentiles amongst whom I constantly move may not know I am a Jew'. ${ }^{133}$ Thus disguised, he is able to render sympathetic assistance to the Jews, keeping the sexes separate and protecting Jewish women from being raped. ${ }^{134}$

Second, where direct speech was too dangerous, written correspondence might be less so. Apollonius and Musonius 'carried on a correspondence through Menippus and Damis, who went to and fro the prison' ${ }^{135}$ Omitting such of their letters as did not handle great themes', Philostratus includes for his readers 'the more important ones in which we get glimpses of lofty topics'. ${ }^{136}$ The letters are obtuse and quite inoffensive from a judicial or political perspective, treating nothing of import to Musonius' case nor implicating Apollonius in any illegal action. ${ }^{137}$

Finally, there was no substitute, whatever other strategies were employed, for acting and speaking prudently when in the hearing of prison officials and strangers.

The Jailer of Philippi: The Philippian jailer finds himself in a similar predicament to that of the jailer of the Talmudic vision as he renders care and assistance to Paul and Silas at Acts 16 in what has become an extremely anti-Jewish climate. In helping the prisoners as he did, has the jailer acted illegally? Bruce says no. 'The jailer was guilty of no dereliction of duty in thus taking two prisoners into his house, his responsibility was to produce them when called upon to do so. He had no reason to

${ }^{133}$ Talm. Mo'ed VII: Ta'an. $22 a$.

${ }^{134}$ Ibid.

135Philostratus, VA 4.46.

136 Ibid.

${ }^{137}$ Note how Paul gives in his prison epistles (e.g., Col. 4:7-9) what might be termed 'harmless details' of his circumstances. He promises, however, that those individuals whom he sends will disclose in detail the state of affairs with him. 
fear that they would run away and leave him in the lurch'. ${ }^{138}$ This assertion, however, runs up against juridical texts which seem to suggest that he did act illegally and could have been charged with so doing.

Consider first the matter of the softening of Paul's confinement. Both magistrates and prison guards were accountable in law for how they kept prisoners. Laxness in the method of constraint, especially if prisoners escaped as a result, was punishable. Quoting earlier rules, Venuleius Saturninus (2nd-3rd century AD) writes: 'If you should establish that any persons kept in fetters have been released by the magistrates hastily and without cause, you shall order them to be bound and shall impose a fine on those who released them' ${ }^{139}$ The jurist Paulus (2nd-3rd century AD) provides that if the officer in charge of a prison is bribed to keep someone in custody without chains,. . .he must be punished by the court; if he was ignorant of the fact, he should be removed from his post for negligence'. ${ }^{140}$ A rescript of Hadrian (117-138 AD) to Salvius provides that 'punishment must be imposed on him who has set a prisoner at large or has knowingly kept him in such a way that the prisoner is able to

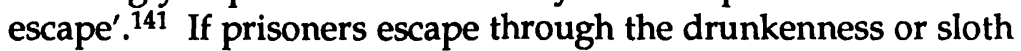
of the guard, he was 'corporally punished and transferred to inferior military duties'. ${ }^{142}$ Callistratus (2nd-3rd century AD), in citing this Hadrianic rescript, ventures the view that the same provisions should also apply to guards who keep individuals in civilian custody. ${ }^{143}$

That such punitive provisions for improperly keeping prisoners existed in the NT period is indicated by the record of Agrippa's imprisonment (37 AD). Even with the special provisions allow-ed by the praetorian prefect Macro, Agrippa should apparently have been kept in chains. That he wasn't so kept and that this breach was a danger to the centurion who

\footnotetext{
${ }^{138}$ Bruce, Book of Acts 318. Cf. Ramsay, op. cit. 222. 'He was responsible for producing his prisoner when called for; but it was left to himself to keep them as he thought best'.

${ }^{139}$ Dig. 48.3.10.

140Ibid. 48.3.8.

${ }^{141}$ Ibid. 48.3.12.

142 Ibid.

${ }^{143}$ Dig. 48.3.12.1.
} 
had charge of him is evident. Out of fear for his personal safety on hearing the report that Tiberius is not dead, the centurion orders 'the manacles to be put on Agrippa, though he had previously taken them off, and a stricter guard to be kept than before'. ${ }^{144}$

The Philippian magistrates give the jailer instructions that Paul and Silas are to be imprisoned securely (16:23). Their placement in the inner prison with feet secured in stocks constitutes his compliance with the command (16:24). Following the earthquake, he does not immediately re-shackle the apostles. Rather, the text indicates that he removes his prisoners not only from the inner prison but from the prison proper to his own house.

As Bruce and Ramsay indicate, Paul and Silas are still legally the jailer's wards. However, they are no longer in the expected or required confinement from the magistrates' perspective. This action, moreover, is a contravention of the orders given him in that it effectively softens their punishment. The Western text (16:30) apparently attempts to shelter the jailer from the charge of negligence and illegality when it adds that "the jailer "secured the rest" of the prisoners before he addressed Paul and Silas (after $€ \xi \omega \mathrm{D}$ syrh with * read roù $s$

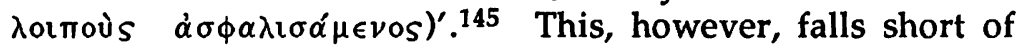
exonerating the jailer. Punishments similar to those mentioned above may apply to him should his actions be discovered.

The jailer may be incurring even greater risk in providing a meal for the prisoners Paul and Silas. When news came to the prisoner Agrippa that Tiberius was dead, the centurion guarding him 'joined in the rejoicing at the news because it was to Agrippa's advantage and treated him to a dinner' ${ }^{146}$ While they were feasting and drinking, another report came that Tiberius had not died. Josephus records that the centurion was deeply perturbed at this report 'since the penalty set for such things as he had done was death, that is, both to have dined

144.josephus, Ant. 18.233 [18.6.10].

${ }^{145}$ B.M. Metzger, A Textual Commentary on the Greek New Testament (London/New York, UBS 1975) 449. See the rather harsh assessment of Ramsay's positive comments on the authenticity of the Western text.

146Josephus, Ant. 18.231 [18.6.10]. 
together with a prisoner and to have rejoiced at the news of the emperor's death. . $\therefore$ Wh7 Whatever the purpose of the meal, dining with a prisoner is clearly indicated as a separate offence. When the jailer offers his prisoners hospitality, he certainly does something that is very unusual. It may also, by analogy to the Agrippa incident, constitute a chargeable offence, whether capital or otherwise.

The jailer's actions are illegal, or grossly improper at the very least. However, seen within the context of the above discussion of Christian risk-taking to help the prisoner, they take on a new light. The jailer before his conversion shows an overweaned sense of responsibility ${ }^{148}$ in being prepared to take his own life because of the apparent escape of his prisoners; as a Christian, he casts caution and concern for legal niceties aside in his zeal to help the prisoners who have converted him. Is there need to defend him or simply praise him?

\section{Conclusions}

If, as we are frequently advised, the prisoner Paul went from victory to victory, we may be sure from this study that he did not do it alone. Christian individuals and groups who assisted Paul when he was free to carry out his missionary labours were critical in sustaining both him and his mission during his imprisonments.

Luke shows his readers Christian co-workers who stand by the prisoner apostle rather than taking the easier and safer route of abandoning him. Luke and Aristarchus 'cover' Paul with what status they have and show physical solidarity, voluntarily accompanying him at cost and risk to themselves when he goes to Rome. The assistance of humble Christians is also recounted. The Philippian jailer demonstrates remarkable bravery by attending to the pressing physical needs of the imprisoned missionaries Paul and Silas and by mitigating the rigours of their confinement. He helps in an anti-Semitic climate and knowingly disobeys the explicit instructions of his

${ }^{147}$ Ibid. 18.232 [18.6.10].

${ }^{148} \mathrm{Dig}$. indicates at several places that the circumstances of escape are taken into consideration in assessing culpability and assigning punishment. Surely an act of God such as an earthquake would at least have mitigated, if not completely eliminated, any punitive consequences. 
superiors, thus incurring great risk to himself. Finally, Luke portrays churches playing a vital role in helping as well. The Roman church-far from ignoring Paul or showing hostility as some scholars would have us believe-greatly encourages an anxious prisoner Paul by first embracing him officially and at its highest levels of leadership as a sign of its solidarity with him in his plight and then facilitating his preaching in the capital city.

This study has touched upon the matter of Christian helpers and helping behaviours in the book of Acts. There are other helpers of the prisoner Paul, among them family members and unbelieving strangers, who are mentioned not only in Acts but also in the Pauline epistles. And beyond emotional help, there are indications of material and spiritual help rendered to Paul and many others throughout the NT. Set within the broader context of a systematic treatment of prison helpers and helping behaviour in the Greco-Roman world, these too might well disclose interesting and important results. 